\title{
Experimental infection of adult Scapharca broughtonii with Ostreid herpesvirus SB strain
}

\author{
Bai Chang-Ming ${ }^{1}$, Wang Qing-Chen ${ }^{1,2}$, Morga Benjamin ${ }^{3}$, Shi Jie ${ }^{1}$, Wang Chong-Ming ${ }^{1,2, *}$
}

${ }^{1}$ Division of Maricultural Organism Disease Control and Molecular Pathology, Yellow Sea Fisheries Research Institute, Chinese Academy of Fishery Sciences, Qingdao, China

${ }^{2}$ Laboratory for Marine Fisheries and Aquaculture, Qingdao National Laboratory for Marine Science and Technology, Qingdao, China

3 IFREMER, RBE-SG2M-LGPMM, Station de La Tremblade, Avenue de Mus de Loup, F-17390 La Tremblade, France

*Corresponding author : Chong-Ming Wang, email address : wangcm@ysfri.ac.cn

\begin{abstract}
:
We investigated the susceptibility of ark shell, Scapharca broughtonii, adults to Ostreid herpesvirus SB strain (OsHV-1-SB) through experimental infection by intramuscular injection assays. Results showed the onset of mortality occurred at 3 days post injection, one day after the water turbidity became evident in rearing tanks. The mortality curves for the challenged group were similar to those observed at affected hatcheries. Histological lesions, herpesvirus-like particles and high OsHV-1-SB quantities were detected in challenged ark shells. This is the first study to successfully reproduce OsHV-1 disease in Arcoida species, and very few studies in adult bivalves (over 24 months old).
\end{abstract}

\section{Graphical abstract}

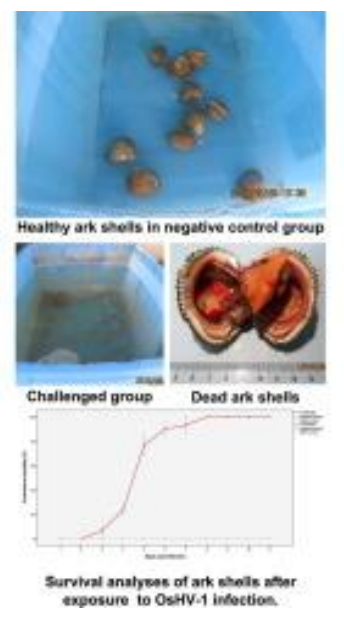




\section{Highlights}

- We examined the pathogenicity of Ostreid herpesvirus SB strain (OsHV-1-SB) on ark shell adults (over 24 months old) through experimental infection by intramuscular injection assays. This is the first study to successfully reproduce the OsHV-1 disease in Arcoida species, and very few studies in adult bivalves (over 24 months old). This study brings new data to better understand interaction between bivalves and OsHV-1.

Keywords: Scapharca broughtonii, Ostreid herpesvirus SB strain, OsHV - 1 - SB, Experimental infection, Viral quantity 


\section{Introduction}

Ostreid herpesvirus-1 (OsHV-1) infections have been reported in association with mass mortalities of several marine bivalve species, notably in their early stages of life (Arzul et al., 2001; Friedman et al., 2005; Hine et al., 1992; Wang et al., 2002). There were also a few cases of mortalities in bivalve adults (over 24 months old) associated with different OsHV-1 variants, such as acute viral necrobiotic virus (AVNV) (Wang et al., 2002), OsHV-1 $\mu$ var (Paul-Pont et al., 2014; Whittington et al., 2015) and Ostreid herpesvirus SB strain (OsHV-1-SB) (Bai et al., 2016). But in most cases, OsHV-1 and its variants (OsHV-1 $\mu$ var) were always detected in normal appearing adult bivalves or only a weak link between viral infections and mortalities of bivalve adults (over 24 months old) (Arzul et al., 2002; Jee et al., 2013; Paul-Pont et al., 2014; Shimahara et al., 2012). Several attempts have been reported to experimentally reproduce the pathogenicity of OsHV-1 or its variants on adult (over 24 months old) Zhikong scallops (Wang et al., 2004) and Pacific oysters (Azema et al., 2016; Green et al., 2016; Segarra et al., 2014a). Reported cumulative mortalities were about 70\% in Zhikong scallop (Wang et al., 2004), and varied from 0 to $40 \%$ in Pacific oysters mainly due to divergent resistance to OsHV-1 infections among different oyster families (Azema et al., 2016; Green et al., 2016; Segarra et al., 2014a) .

Since 2012, sporadic high mortalities of ark shell, Scapharca broughtonii, broodstocks has been reported in hatcheries during breeding seasons (Bai et al., 2016). Epidemiological investigations suggested a causal link between these mortalities and OsHV-1-SB infections (Bai et al., 2016). Experimental infection of ark shell adults with OsHV-1-SB indicated lower mortality rates than those observed in hatcheries (Wang et al., 2016). In the present study, laboratory challenge trials were carried out with the same OsHV-1-SB strain used by Wang et al (2016), but on adult ark shells collected from an area where no history of OsHV-1-SB infection has been reported.

\section{Materials and Methods}

2.1. Origin of ark shells and acclimation period. 150 ark shells (size range 45.52 to $57.80 \mathrm{~mm}$, weight range 73.48 to $94.62 \mathrm{mg}, \mathrm{n}=30$ ) were captured from Chengshantou area, Shandong Province. These ark shells were maintained in fifteen 50L tanks (10 ark shells in each tank) with aerated, filtered, natural sea water at $18.2-19.6^{\circ} \mathrm{C}$, and salinity was fixed at $30 \pm 1 \mathrm{ppt}$. The water was changed daily, and then supplied with adequate quantity of homemade shellfish diet. At the 
end of acclimation period (10 days), 2 individuals were selected randomly from each tank (30 samples in total) and tested negative for OsHV-1-SB by qPCR as described below.

2.2. Experimental infection and sampling. Viral inoculum and negative tissue homogenates were prepared using OsHV-1-SB positive and negative ark shells respectively described by

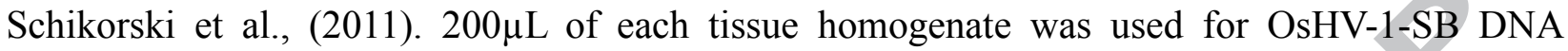
detection and quantification by qPCR.

90 ark shells were anesthetized with $70 \mathrm{~g} / \mathrm{L} \mathrm{MgCl}_{2}$ and randomly divided into challenged, negative and blank control groups (30 ark shells per group). Accordingly, $200 \mu \mathrm{L}$ of viral inoculum $\left(4.2 \times 10^{4}\right.$ copies of viral $\left.\mathrm{DNA} / \mu \mathrm{L}\right)$, negative tissue homogenate or filtered seawater were injected into the foot of each animal. The ark shells for each treatment were then transferred directly to three tanks (50L), and maintained with the same method during acclimation period. Mortality was monitored daily and dead ark shells were removed from tanks. Negative and blank control ark shells were all sacrificed at the end of the experiment. 22-30 mg mantle of each animal were dissected and used for further OsHV-1 detection and quantification.

2.3 OsHV-1 DNA quantification, histopathology and TEM. The detection and quantification of OsHV-1-SB DNA were carried out using qPCR, adapted from a previously published protocol (Martenot et al., 2010), as described by Bai et al. (2016). For negative-staining electron microscopy examination, about $100 \mu \mathrm{L}$ viral inoculum was fixed with $1 \%$ phosphotungstic acid $(\mathrm{pH}$ 7.5) for about 10 minute at room temperature and then examined for the presence of herpesvirus-like particles. Histopathology and TEM examination of ultrathin tissue sections were carried out with five randomly selected moribund ark shells as described by Bai et al. (2016).

\section{Results}

3.1. Ark shell mortality. The water of the challenged group became turbid approximately 2 days post injection (dpi). At 3 dpi, 2 ark shells at the challenged group characterized by fully opening valves, no response after removing from water, pale visceral mass and extensive gill erosion were identified as dead. Meanwhile, some materials colored in deep red were found attaching to the wall of rearing tanks in line just above the water surface of challenged group. And these materials increased gradually and became air-dried at the wall of tank in the following days. The heaviest mortality occurred at $5 \mathrm{dpi}$ (13 ark shells died), and the cumulative mortality reached $76.7 \%$. All 
challenged ark shells were dead at $8 \mathrm{dpi}$, whereas no mortality was observed in negative and blank control groups (Fig. 1).

3.2. OsHV-1 DNA quantification in ark shells. OsHV-1-SB DNA was not detected in negative tissue homogenates and individuals collected from negative and blank control groups. All dead and moribund ark shells in the challenge group were positive for the presence of OsHV-1-SB DNA. The viral quantities ranged from $4.0 \times 10^{3}$ to $6.3 \times 10^{4}$ OsHV-1-SB DNA copies per ng of total DNA, with a mean virus DNA amount estimated to be $2.5 \times 10^{4}$ DNA copies/ng of total DNA (OsHV-1 quantity of each sample will be available upon request).

3.3. Histopathology and TEM. Histopathological changes were observed in the connective tissues of gills, mantles and digestive glands. The most prominent pathological conditions were noted in digestive gland, with dilated digestive tubules and lysed connective tissue distributed throughout the connective tissues (Fig 2A). Accordingly, numerous abnormal cells with enlarged nuclei and chromatin marginalization were also observed on semi-thin sections (Fig 2B). However, eosinophilic intranuclear inclusions were not observed in the present study. Examination of negative-staining viral inoculum showed abundant hexagonal and circular capsids with diameters ranged from $99.37 \mathrm{~nm}$ to $108.84 \mathrm{~nm}$ (Fig 2C). TEM results showed the diameter of nucleocapsids observed in infected nucleus of challenged blood ark shells ranged from $100.81 \mathrm{~nm}$ to $115.71 \mathrm{~nm}$ (Fig 2D). Enveloped virions measuring from $142.28 \mathrm{~nm}$ to 160.63 $\mathrm{nm}$ were also frequently visualized in the intercellular space under epidermal layers (figure not shown).

\section{Discussion}

The high abundance of intra- and extra-cellar herpes-like virus particles in individuals of challenged group suggested lytic infection associated with very high-level replication had occurred in these ark shells. Correspondingly, qPCR analysis revealed high viral quantities in challenged ark shells and absence of OsHV-1-SB in surviving individuals. In addition, the mortality pattern and histopathological changes observed in the present study were similar to naturally infected ark shells (Bai et al., 2016). Altogether, these results suggest a causal link between OsHV-1-SB infections and mortalities of challenged adult ark shells.

The reduced water transparency was the first evident abnormal signs (appeared at 2 dpi) detected 
in the present study, which was followed by onset of mortalities and appearance of deep-red colored materials on the wall of rearing tanks at $3 \mathrm{dpi}$. Similar phenomenon has consistently been observed when we rearing naturally or experimentally infected ark shells in laboratory recently (unpublished data). Considering the paler appearance of the visceral mass and much smaller amount of haemolymph discovered in dead and moribund ark shells compared to healthy individuals, we inferred that excessively secreted mucus and haemolymph could be responsible for the turbid water and appearance of deep-red colored materials observed in the challenged group. The blood of ark shells is red in color, due to a high concentration of hemoglobin in the haemolymph, and so it is very obvious when the haemolymph is secreted into the water. Mucus and haemolymph plays an important role in the immune system and may be secreted in larger volumes due to infection with OsHV-1. The turbid water may indicate that the virus had replicated in ark shells before $2 \mathrm{dpi}$, and provoked the immune responses of ark shells. This was consistent with previous observations that viral quantities have reached over $10^{3}$ copies $/ \mathrm{ng}$ of total DNA at 24 hours after exposure to OsHV-1 in the haemolymph of ark shells (Wang et al., 2016). Studies on adult Pacific oysters also demonstrated that the expression of both viral RNA and host immune genes could be found as early as $0.5 \mathrm{hpi}$ (Segarra et al., 2014a). Similarly, the early replication of OsHV-1 $\mu$ var and reaction of hosts have also been observed in spat of Pacific oysters (Segarra et al., 2014b; Segarra et al., 2014c) and Black-lip pearl oysters (Pinctada margaritifera) (Tan et al., 2015).

Previous studies indicated that OsHV-1 could be considered as the main cause of mortality in $C$. gigas when the viral quantities exceed $10^{4}$ DNA copies per mg of tissue, while viral quantities less than $8.8 \times 10^{3}$ DNA copies per mg tissue are typically associated with a null risk of mortality in infected oysters (Oden et al., 2011). In the present study, high viral quantities of OsHV-1-SB $\left(10^{3}-10^{4}\right.$ per ng of total DNA, correspond to $10^{5}-10^{7}$ DNA copies per mg of tissue) were also only detected in dead or moribund ark shells. Wang et al. (2016) reported that some OsHV-1-SB challenged ark shells with high viral quantities (up to $10^{6}$ per ng of total DNA) have survived 6 days post injection. We concluded that ark shells used by Wang et al. (2016) had a higher threshold of mortality risk compared to those used by the present study.

\section{Acknowledgements}


We thank Wenhui Gao for facilitating the collection and cultivation of blood ark shells used in experimental infection. We also thank Guangbin Liu for providing technical assistance and shellfish diets in the cultivation of ark shells. This research was supported by grants from the China Agriculture Research System (Project No. CARS-48), the National Natural Science Foundation of China under Grant No. 31502208 and the Scientific and Technological Innovation Project financially supported by Qingdao National Laboratory for Marine Science and Technology (No. 2015ASKJ01). 


\section{References}

Arzul, I., Nicolas, J. L., Davison, A. J., Renault, T., 2001. French scallops: A new host for Ostreid herpesvirus-1. Virology. 290, 342-349.

Arzul, I., Renault, T., Thebault, A., Gerard, A., 2002. Detection of oyster herpesvirus DNA and proteins in asymptomatic Crassostrea gigas adults. Virus Res. 84, 151-160.

Azema, P., Travers, M. A., Benabdelmouna, A., Degremont, L., 2016. Single or dual experimental infections with Vibrio aestuarianus and OsHV-1 in diploid and triploid Crassostrea gigas at the spat, juvenile and adult stages. J. Invertebr. Pathol. 139, 92-101.

Bai, C., Gao, W., Wang, C., Yu, T., Zhang, T., Qiu, Z., Wang, Q., Huang, J., 2016. Identification and characterization of ostreid herpesvirus 1 associated with massive mortalities of Scapharca broughtonii broodstocks in China. Dis. Aquat. Org. 118, 65-75.

Friedman, C. S., Estes, R. M., Stokes, N. A., Burge, C. A., Hargove, J. S., Barber, B. J., Elston, R. A., Burreson, E. M., Reece, K. S., 2005. Herpes virus in juvenile Pacific oysters Crassostrea gigas from Tomales Bay, California, coincides with summer mortality episodes. Dis. Aquat. Org. 63, 33-41.

Green, T. J., Vergnes, A., Montagnani, C., de Lorgeril, J., 2016. Distinct immune responses of juvenile and adult oysters (Crassostrea gigas) to viral and bacterial infections. Vet. Res. 47,72 .

Hine, P., Wesney, B., Hay, B., 1992. Herpesviruses associated with mortalities among hatchery-reared larval Pacific oysters, Crassostrea-gigas. Dis. Aquat. Org. 12, 135-142.

Jee, B. Y., Lee, S. J., Cho, M. Y., Lee, S. J., Kim, J. W., Choi, S. H., Do Jeong, H., Kim, K. H., 2013. Detection of Ostreid herpesvirus 1 from adult Pacific oysters Crassostrea gigas cultured in Korea. Fish. Aquat. Sci. 16, 131-135.

López Sanmartín, M., Power, D. M., de la Herran, R., Navas, J. I., Batista, F. M., 2016. Experimental infection of European flat oyster Ostrea edulis with ostreid herpesvirus 1 $\mu$ var (OsHV-1 $\mu$ var): Mortality, viral load and detection of viral transcripts by in situ hybridization. Virus Res. 217, 55-62.

Martenot, C., Oden, E., Travaille, E., Malas, J. P., Houssin, M., 2010. Comparison of two real-time PCR methods for detection of ostreid herpesvirus 1 in the Pacific oyster Crassostrea gigas. J. Virol. Methods. 170, 86-89. 
Oden, E., Martenot, C., Berthaux, M., Travaille, E., Malas, J. P., Houssin, M., 2011. Quantification of ostreid herpesvirus $1(\mathrm{OsHV}-1)$ in Crassostrea gigas by real-time PCR: Determination of a viral load threshold to prevent summer mortalities. Aquaculture. 317, 27-31.

Paul-Pont, I., Evans, O., Dhand, N. K., Rubio, A., Coad, P., Whittington, R. J., 2014. Descriptive epidemiology of mass mortality due to Ostreid herpesvirus-1 (OsHV-1) in commercially farmed Pacific oysters (Crassostrea gigas) in the Hawkesbury River estuary, Australia. Aquaculture. 422, 146-159.

Schikorski, D., Renault, T., Saulnier, D., Faury, N., Moreau, P., Pepin, J. F., 2011. Experimental infection of Pacific oyster Crassostrea gigas spat by ostreid herpesvirus 1: demonstration of oyster spat susceptibility. Vet. Res. 42.

Segarra, A., Baillon, L., Tourbiez, D., Benabdelmouna, A., Faury, N., Bourgougnon, N., Renault, T., 2014a. Ostreid herpesvirus type 1 replication and host response in adult Pacific oysters, Crassostrea gigas. Vet. Res. 45, 103.

Segarra, A., Faury, N., Pepin, J. F., Renault, T., 2014b. Transcriptomic study of 39 ostreid herpesvirus 1 genes during an experimental infection. J. Invertebr. Pathol. 119, 5-11.

Segarra, A., Mauduit, F., Faury, N., Trancart, S., Dégremont, L., Tourbiez, D., Haffner, P., Barbosa-Solomieu, V., Pepin, J. F., Travers, M. A., Renault, T., 2014c. Dual transcriptomics of virus-host interactions: comparing two Pacific oyster families presenting contrasted susceptibility to ostreid herpesvirus 1. BMC Genomics. 15, 580.

Shimahara, Y., Kurita, J., Kiryu, I., Nishioka, T., Yuasa, K., Kawana, M., Kamaishi, T., Oseko, N., 2012. Surveillance of Type 1 Ostreid Herpesvirus (OsHV-1) Variants in Japan. Fish Pathol. 47, 129-136.

Tan, T. L., Paul-Pont, I., Evans, O. M., Watterson, D., Young, P., Whittington, R., Fougerouse, A., Bichet, H., Barnes, A. C., Dang, C., 2015. Resistance of Black-lip learl oyster, Pinctada margaritifera, to infection by Ostreid herpes virus $1 \mu$ var under experimental challenge may be mediated by humoral antiviral activity. Fish Shellfish Immunol. 44, 232-40.

Wang, C., Wang, X., Ai, H., Li, Y., He, G., Huang, J., Song, W., 2004. The viral pathogen of massive mortality in Chlamys farreri. J. Fish. China. 28, 547-553.

Wang, C., Wang, X., Song, X., Huang, J., Song, W., 2002. Purification and ultrastructure of a 
spherical virus in cultured scallop Chlamys farreri. J. Fish. China. 26, 180-184.

Wang, Q., Bai, C., Zhang, T., Wang, C., Qiu, Z., Huang, J., 2016. Pathogenicity of Ostreid herpesvirus-1 to Scapharca broughtonii. J. Fish. China. 40, 468-474.

Whittington, R. J., Dhand, N. K., Evans, O., Paul-Pont, I., 2015. Further observations on the influence of husbandry practices on OsHV-1 mu Var mortality in Pacific oysters Crassostrea gigas: Age, cultivation structures and growing height. Aquaculture. 438, $82-97$. 


\section{Figure legends}

Fig. 1. Cumulative mortalities $( \pm \mathrm{SE})$ of Scapharca broughtonii asults, after exposing to Ostreid herpesvirus SB strain and control (negative and blank) inoculum.

Fig. 2. Histopathological and transmission electron microscopy examination of infected Scapharca broughtonii adults. (A) Lysed tubule dilation (arrows) and abnormal nuclei (arrowheads) observed in digestive gland of S. broughtonii collected from the challenged group (scar bar $=20 \mu \mathrm{m})$. Y: yellowish material typically associated with Ostreid herpesvirus SB strain infection. (B) Semi-thin sections of mantle showing significant lysed tissue consisted of enlarged nuclei (arrows) associated with abnormal marginated chromatin (scar bar $=10 \mu \mathrm{m})$. (C) Naked nucleocapsid detected in viral inoculum (scar bar $=50 \mathrm{~nm}$ ). (D) A nuclear filled with nucleocapsids (arrows) detected in the mantle of infected $S$. broughtonii (scar bar $=1 \mu \mathrm{m}$ ). 

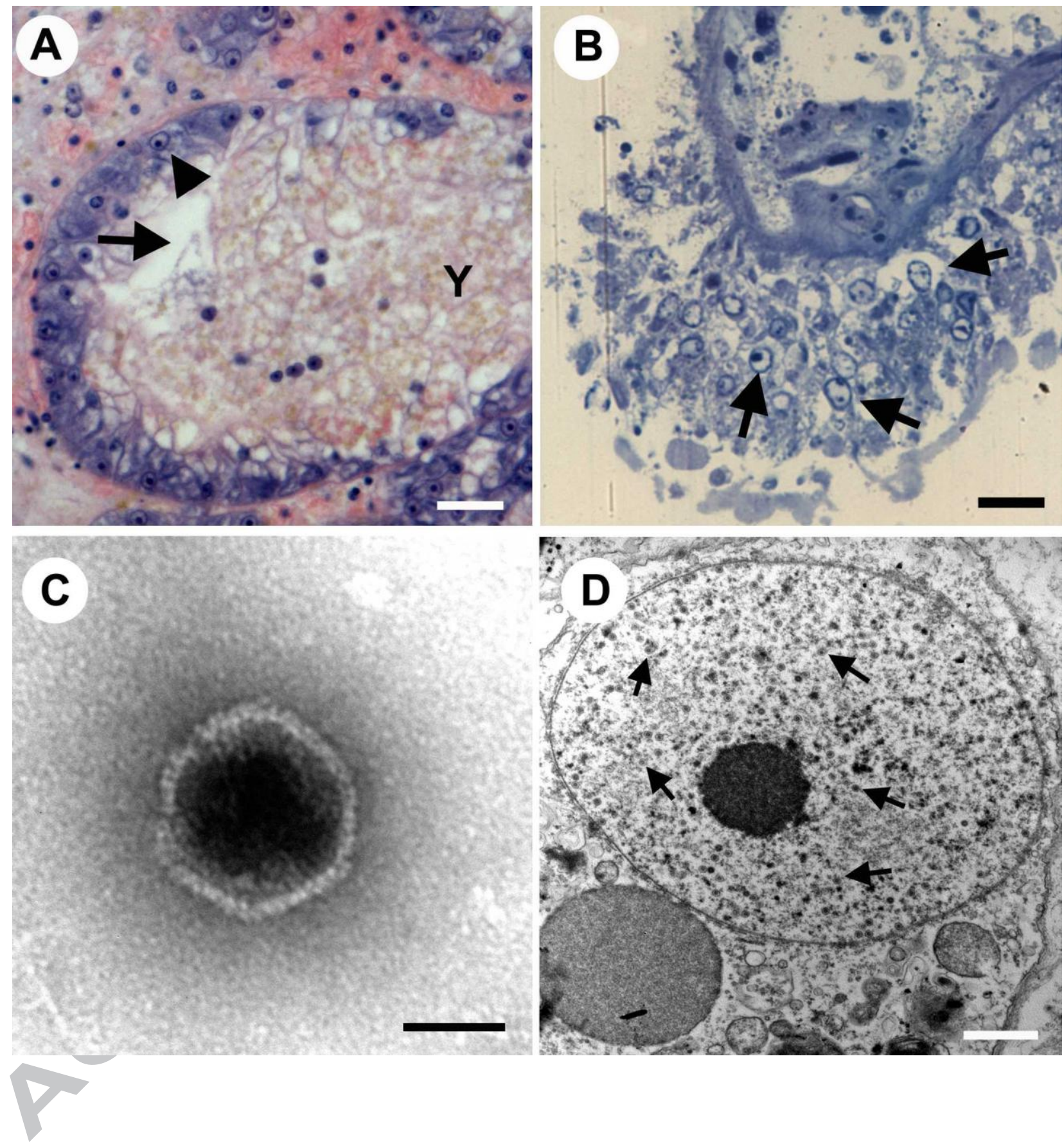


\section{ACCEPTED MANUSCRIPT}
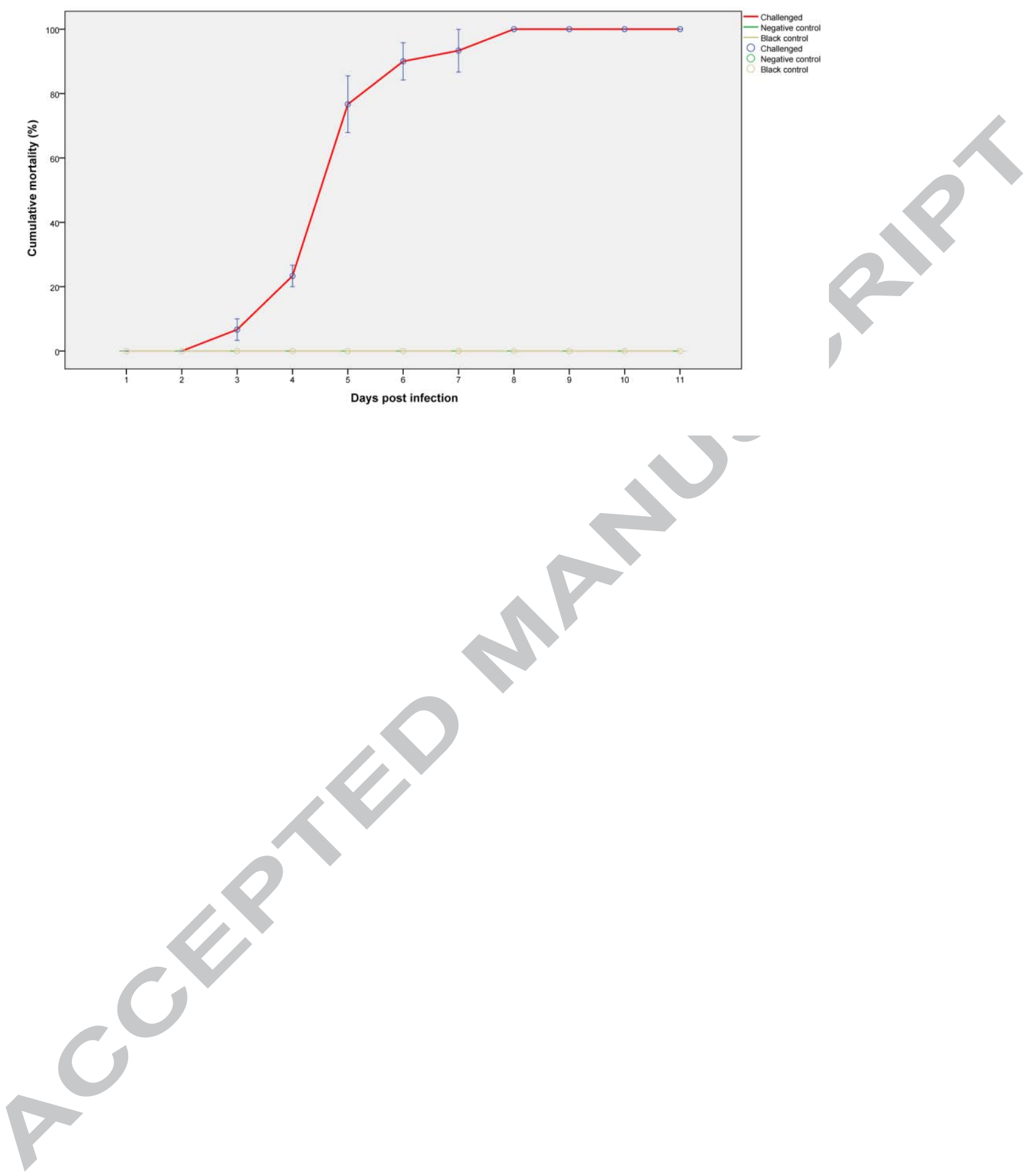


\section{Healthy ark shells in negative control group}

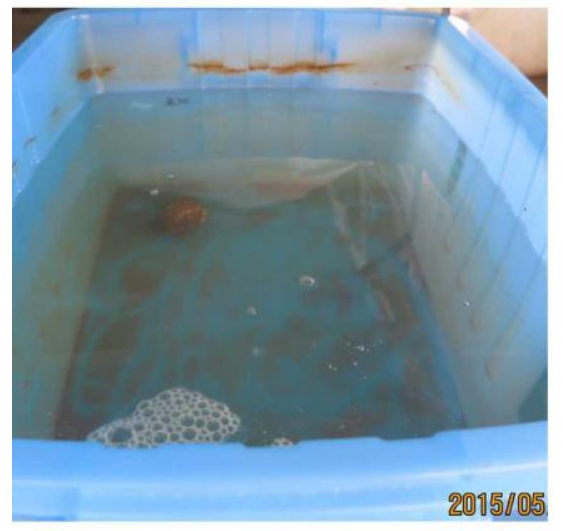

Challenged group
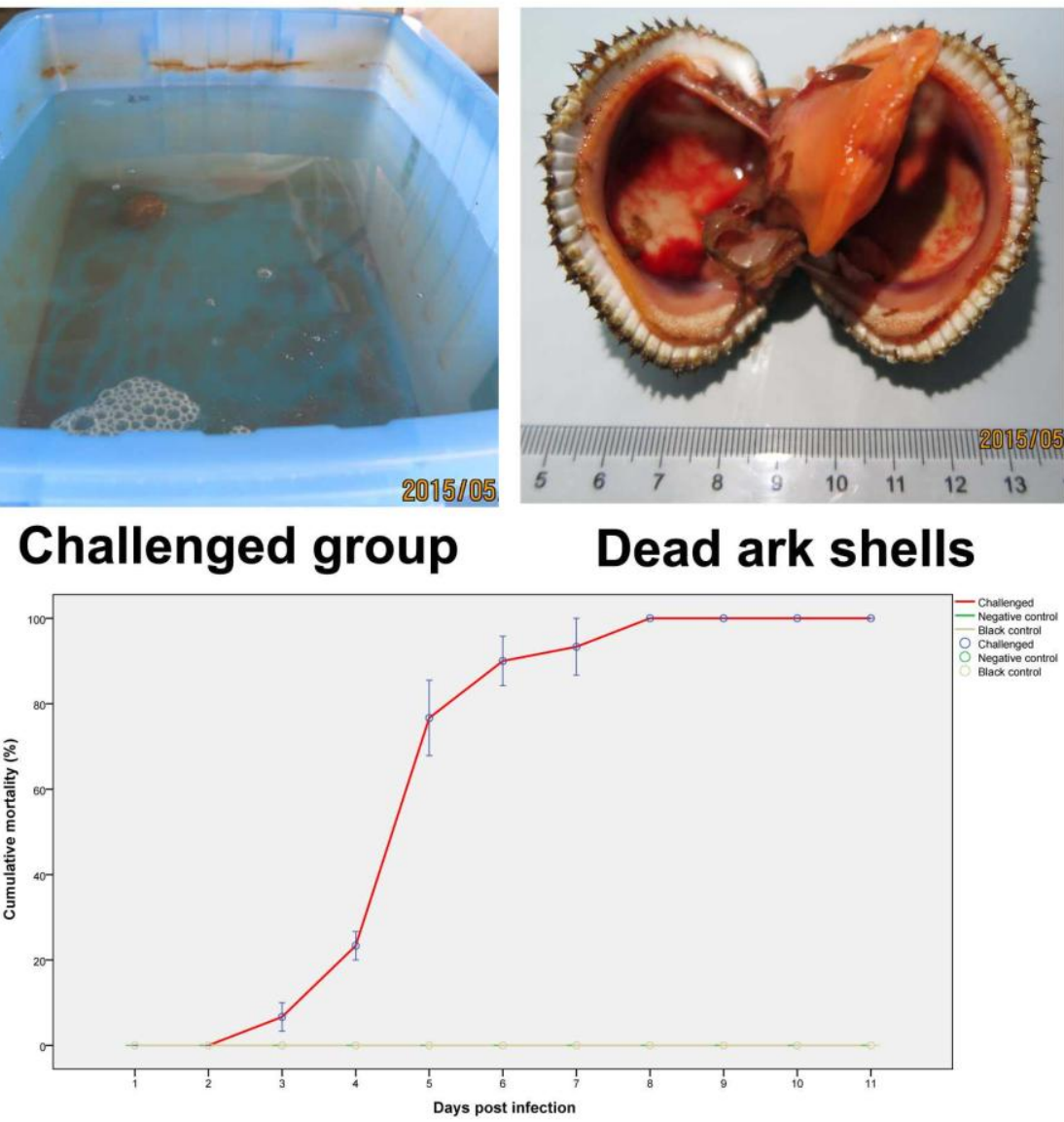

Survival analyses of ark shells after exposure to OsHV-1 infection. 